\title{
ART
}

\section{TECHNICAL FEATURES OF COLOUR SYSTEM DEVELOPMENT IN ELECTRONIC ADVERTISING}

\author{
Hussain Abdulalee Falh Almnshdawy, PhD. College of media University of Thi-Qar
}

DOI: https://doi.org/10.31435/rsglobal_ws/30092019/6699

\begin{abstract}
ARTICLE INFO
Received: 29 July 2019

Accepted: 22 September 2019

Published: 30 September 2019

\section{KEYWORDS}

colour system, electronic advertising, banner advertising, contextual advertising, advertising block, colour perception, banner blindness.

ABSTRACT

The objective of the work is to analyze the technical features of the development of colour system in electronic advertising and to identify ways of solving the main problems.

Research methodology. The methodology of this research paper is based on a project approach, which involves the analysis and identification of problems in the development of colour systems in electronic advertising. Electronic advertising has its distinct features, which are caused by the process of its creation. The specifics of the work required the involvement of various theoretical sources on colouring, the psychology of colour perception, computer modelling, as well as statistics.

The scientific novelty of this study is to identify the most problematic moments in the perception of electronic advertising and find ways to solve them, i.e. optimization of the colour system in accordance with the characteristics of the target audience and the nature of the web page design.
\end{abstract}

Citation: Hussain Abdulalee Falh Almnshdawy. (2019) Technical Features of Colour System Development in Electronic Advertising. World Science. 9(49), Vol.1. doi: 10.31435/rsglobal_ws/30092019/6699

Copyright: (C) 2019 Hussain Abdulalee Falh Almnshdawy. This is an open-access article distributed under the terms of the Creative Commons Attribution License (CC BY). The use, distribution or reproduction in other forums is permitted, provided the original author(s) or licensor are credited and that the original publication in this journal is cited, in accordance with accepted academic practice. No use, distribution or reproduction is permitted which does not comply with these terms.

Problem statement. Advertising now serves as an important marketing element [8, p. 100]. Advertising message is the main tool for the implementation of advertising tasks. The effectiveness of advertising messages depends on their content and design [9, p. 46-47]. The electronic advertising environment has its own characteristics that affect the format of advertising messages. Advertising on the Internet is evolving, which is strongly reflected in its design [13, p. 67-68]. Colour as an active element of design and visual accent has great potential for use for advertising purposes, including electronic one. Therefore, the urgent problem is studying technical nuances of using colour in advertising messages on Internet resources that are of the greatest demand in the modern communication space.

The study aims at analyzing the technical features of developing a colour system in electronic advertising and to identify ways of solving the main problems.

Outline of the research material. Advertising on the Internet has its own specifics in the context of peculiarities of the formation of communicative elements on this resource as a whole [5]. There are currently recommendations for developing websites, online stores, etc. However, it should be taken into account that a well-designed page and advertisement are not the key to the success of the campaign. They should work in a single concept.

When browsing the page, during the last 4-7 seconds the user decides what to do next: return to the search engine or click on the advertisement presented on the page. In this choice, an important role is played by the colour design of the website and advertisements placed on it $[2,3]$.

Basic 8 colours are used for the design of websites. These colours work when placing ad units on them in the following way. The information is presented according to the research of Oxford University psychologists [4]. It gives an idea of what people are doing when they study web pages made in a specific colour scheme. The reactions of users to the basic colour of the website are based 
on their further actions, which determine the degree of probability that the advertisement will be noticed and will receive any response.

The website designed in red colours subconsciously causes tension, so users do not linger on its pages. In this case, contextual advertising is not perceived. Banner advertising looks inappropriate (Table 1, item 1).

The white colour of the page is associated with a book or magazine, it does not provoke the search for advertising (Table 1, item 2). Advertising that uses the same colours as the page layout is perceived as a continuation of the website and does not attract attention. The winning option here is banners that are perceived by users as the ability to access the same comfortable information. Contextual advertising can also be effective if bright colours are used in the headline design. From the standpoint of the psychology of perception, the following colours will be the most effective: turquoise, purple, saturated pink and yellow.

When using a white background for the website, the ad units with a coloured backing or frame will give the impression of falling out of the general context. Thus, the users eliminate them from the field of their attention, because they visit website, most often, with a specific purpose, being interested in a narrow topic. Anything that does not apply is automatically ignored from a time-saving standpoint - users got used to the abundance of unnecessary information and try to fend off it immediately.

Using black as the main colour for the website contributes to the unconscious slowing down of mental processes, $50 \%$ of users immediately leave the page. The rest will intuitively look for a "way out", which may be an ad unit. But for that purpose, it must be noticeable. This can be achieved by using a bright background and fonts for the ad unit, as well as a frame (Table 1, item 3).

Yellow is distinguished among the main colours. It has been called "end-to-end" because it is the safest for perception (Table 1, item 4). The yellow background causes lingering at the page, despite its content. The page is seen as a starting point that gives you the choice. Again, advertisements should be decorated using colours contrasting with yellow. Polychromy may be used here - ads may differ in colour, which will create the illusion of diversity of choice. Users want to see several ad units at once. At the same time, banner advertising almost does not work on such a website.

Green colour for the design of the website can give different results (Table 1, item 5). It all depends on the shade and saturation. These colour characteristics are of the greatest importance for those websites where the filling of this colour is more than $60 \%$. Banner advertising works well on such websites. Contextual advertising is perceived by users when it is created according to the "bulletin board" principle, not in the form of separate scattered elements.

Blue is quite often used for website design, and in its different shades (Table 1, item 6). Bright and light shades of blue are used for children's websites and everything related to the sea. These shades are inherent in websites selling "democratic" goods. For websites in this colour gamut, banner advertising will work if it becomes a continuation of a trade offer or specific reference information presented on the website. Contextual advertising shall have a white background, text on it shall be black or close to it.

Dark shades of blue (as well as maroon) create a feeling of luxury, confidence. Therefore, advertising will be effective only if it is designed in the same concept with the website.

The website in brown shades if the colour was muted was recognized as one of the most successful solutions (Table 1, item 7). With such a background, both banner and contextual advertising work well. The soft shades of brown have a soothing effect. They are neutral in relation to the information presented on the website, do not interfere with its perception. This also applies to advertising.

The website with a gray background (with black, red, white as additional colours) have the least potential for advertising (Table 1, item 8). Such design causes boredom, which leads to leaving the page.

Table 1.

\begin{tabular}{|l|l|c|c|}
\hline $\begin{array}{l}\text { Item } \\
\text { No. }\end{array}$ & $\begin{array}{l}\text { Main colour } \\
\text { (background) }\end{array}$ & Page (look) & Colour palette \\
\hline 1 & 2 & 3 & 4 \\
\hline 1 & red & & \\
\end{tabular}


Continuation of table 1.

\begin{tabular}{|c|c|c|c|}
\hline 1 & 2 & 3 & 4 \\
\hline 2 & white & 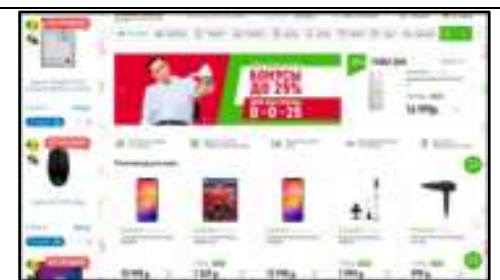 & \\
\hline 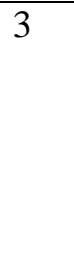 & black & 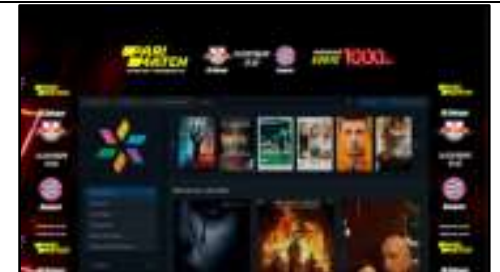 & \\
\hline 4 & yellow / orange & 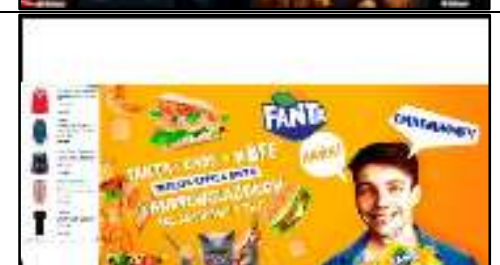 & \\
\hline 5 & green & 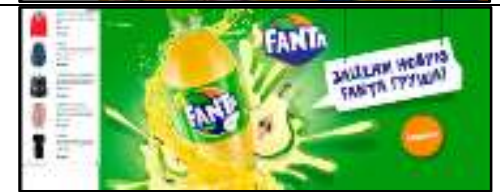 & \\
\hline 6 & blue & 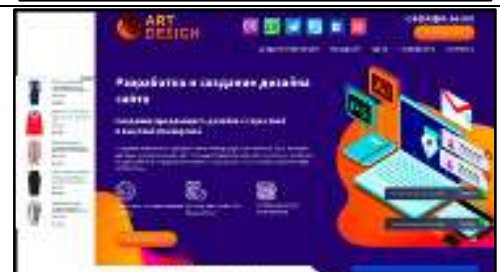 & \\
\hline 7 & brown & 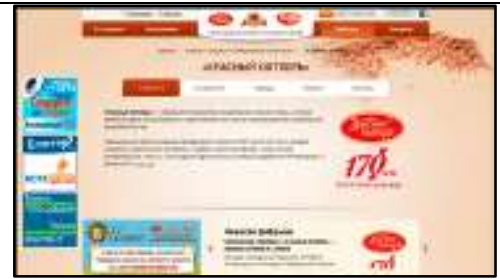 & \\
\hline 8 & gray & 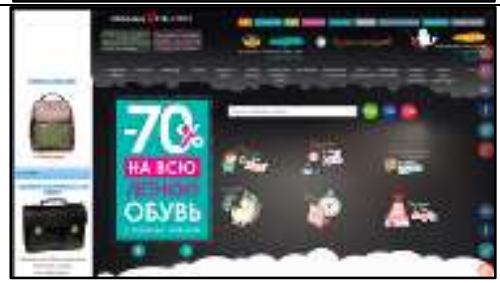 & \\
\hline
\end{tabular}

One of the problems that hinders the effectiveness of online advertising is the so-called banner blindness [1]. Banner blindness is the natural reaction of the human psyche to the excess of information [8, p. 98]. Experts currently note the development of content blindness.

In addition to the fact that the human brain quickly learns to ignore unnecessary information, they often choose the wrong places to place banners - they fall into blind areas that are almost not within the area of user content perception when visiting the website $[10, p$. 113]. The perception patterns are presented in Figure 1.

There is currently a large number of research on the effect of colour on the human psyche. In this case, we have selected the information that allows you to most effectively choose the colour to create the banner. The two most significant factors influencing colour perception are the evolutionary-biological 
memory of a person and his/her personal experience [6] (Table 2). The audience that the advertisement is designed for can often have their own collective experience, driven by their area of interest.

Let's analyze the most commonly used colours from the standpoint of their efficiency and the nature of the message.
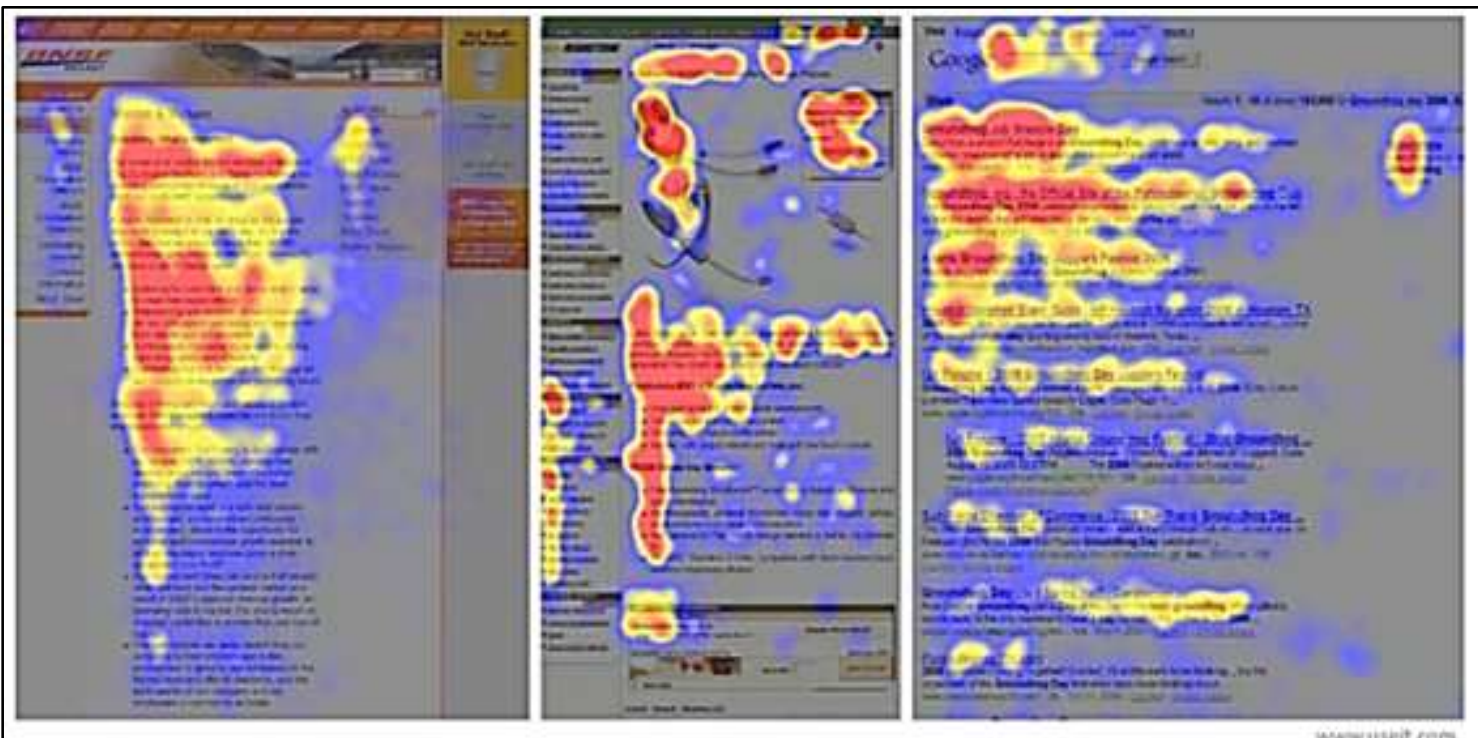

Fig. 1. The perception patterns

Hot spots are highlighted in red and orange

There are two main types of tools used to effect the user: location and colour. The user should notice the banner when entering the website page and then become interested in it [7]. Let's focus on the issue of using colour to stimulate the desired user response.

Table 2. Colour semantics in different countries

\begin{tabular}{|c|c|c|c|c|c|c|c|}
\hline & $\begin{array}{l}\text { Great } \\
\text { Britain }\end{array}$ & USA & China & India & Egypt & France & Japan \\
\hline red & $\begin{array}{l}\text { danger } \\
\text { love } \\
\text { stop }\end{array}$ & $\begin{array}{l}\text { danger } \\
\text { love } \\
\text { stop }\end{array}$ & $\begin{array}{c}\text { luck } \\
\text { fate } \\
\text { enjoyment }\end{array}$ & $\begin{array}{c}\text { fate } \\
\text { rage } \\
\text { courage }\end{array}$ & death & elite & $\begin{array}{c}\text { evil } \\
\text { danger }\end{array}$ \\
\hline orange & calmness & $\begin{array}{l}\text { confidence } \\
\text { reliability } \\
\text { community }\end{array}$ & $\begin{array}{c}\text { luck } \\
\text { fate } \\
\text { enjoyment }\end{array}$ & $\begin{array}{c}\text { sadness } \\
\text { disgust } \\
\text { fear }\end{array}$ & $\begin{array}{l}\text { virtue } \\
\text { conscience } \\
\text { truth }\end{array}$ & $\begin{array}{l}\text { freedom } \\
\text { peace }\end{array}$ & $\begin{array}{l}\text { future } \\
\text { youth } \\
\text { energy }\end{array}$ \\
\hline yellow & $\begin{array}{c}\text { cowardice } \\
\text { enjoyment } \\
\text { hope }\end{array}$ & $\begin{array}{l}\text { cowardice } \\
\text { enjoyment } \\
\text { hope }\end{array}$ & $\begin{array}{c}\text { power } \\
\text { earth } \\
\text { might }\end{array}$ & holiday & grief & impermanence & $\begin{array}{c}\text { grace } \\
\text { nobility }\end{array}$ \\
\hline green & $\begin{array}{l}\text { spring } \\
\text { nature } \\
\text { way }\end{array}$ & $\begin{array}{l}\text { spring } \\
\text { money } \\
\text { novelty }\end{array}$ & $\begin{array}{l}\text { health } \\
\text { prosperity } \\
\text { harmony }\end{array}$ & $\begin{array}{c}\text { romance } \\
\text { novelty } \\
\text { yield }\end{array}$ & $\begin{array}{l}\text { happiness } \\
\text { prosperity }\end{array}$ & $\begin{array}{l}\text { abundance } \\
\text { strength }\end{array}$ & $\begin{array}{l}\text { eternal } \\
\text { life }\end{array}$ \\
\hline blue & $\begin{array}{c}\text { power } \\
\text { calmness }\end{array}$ & $\begin{array}{l}\text { confidence } \\
\text { community } \\
\text { corporate } \\
\text { identity }\end{array}$ & $\begin{array}{l}\text { heaven } \\
\text { clouds }\end{array}$ & $\begin{array}{c}\text { grief } \\
\text { disgust } \\
\text { relaxation }\end{array}$ & $\begin{array}{l}\text { virtue } \\
\text { conscience } \\
\text { truth }\end{array}$ & $\begin{array}{l}\text { freedom } \\
\text { peace }\end{array}$ & atrocity \\
\hline purple & power & $\begin{array}{c}\text { power } \\
\text { imagination }\end{array}$ & power & misery & virtue & $\begin{array}{c}\text { freedom } \\
\text { peace }\end{array}$ & power \\
\hline black & $\begin{array}{l}\text { funeral } \\
\text { death } \\
\text { grief }\end{array}$ & $\begin{array}{l}\text { funeral } \\
\text { death } \\
\text { evil }\end{array}$ & $\begin{array}{l}\text { heaven } \\
\text { neutral } \\
\text { high } \\
\text { quality }\end{array}$ & evil & - & 2. & $\begin{array}{l}\text { death } \\
\text { evil }\end{array}$ \\
\hline white & $\begin{array}{l}\text { purity } \\
\text { chastity } \\
\text { holiness }\end{array}$ & $\begin{array}{c}\text { purity } \\
\text { peace } \\
\text { holiness }\end{array}$ & grief & $\begin{array}{c}\text { fun } \\
\text { calmness } \\
\text { harmony }\end{array}$ & joy & neutral & $\begin{array}{l}\text { purity } \\
\text { holiness }\end{array}$ \\
\hline
\end{tabular}


Red always attracts attention, which is caused by evolutionary memory (Table 3, item 1). It also allows bringing the image to the fore visually. Red is associated with sensations such as dynamics, movement, speed, risk, passion, sensation, high temperature. Persistent associations are formed on the basis of feelings: high temperature - hot drinks or antipyretics, passion, love - the theme of "intimacy"; speed, risk - the colour of Ferrari, etc.

With a large number of associations and a high degree of "noticeability", the choice of red has its potential risks. The use of red in large proportions causes irritation, aggression. If there are red elements on the page besides the banner, it will level its "noticeability". In addition, regular Internet users have a persistent binding of red to advertising, so a banner in this colour, although it will be noticed in the first seconds of stay on the website, will cause rejection, ignore.

Orange is a bright colour that evokes positive emotions (Table 3, item 2). Most often it is used not as the primary colour of the banner, but as an accent. The following associations correspond to orange: cheerfulness, health, activity, lightheadedness, sunshine, sweetness. Therefore, it is used to advertise sweets, soft drinks, children's vitamins, sunscreens, travel agencies. In addition, orange causes an association with low prices, online stores, that is acquired (the effects of advertising).

Dark shades of orange are associated with autumn, namely warmth, cosiness, spicy aromas. They are used for advertising household items (plaids, bedspreads, pyjamas), autumn collections, etc.

The use of orange also has its risks. Pure orange can only be used as an accent, since its excess is a strong irritant. Muted shades are perceived more organically, they are perceived as natural at the subconscious level. Orange colour should not be used to advertise "serious" image products.

The yellow colour is also quite bright and well noticeable, and it is not perceived as light-hearted as orange (Table 3, item 3). Yellow is associated primarily with natural products (nuts, honey, cereals). It is a marker of creative, so it is widely used to promote advertising agencies, development courses, etc.

Table 3. Use of colour in advertising

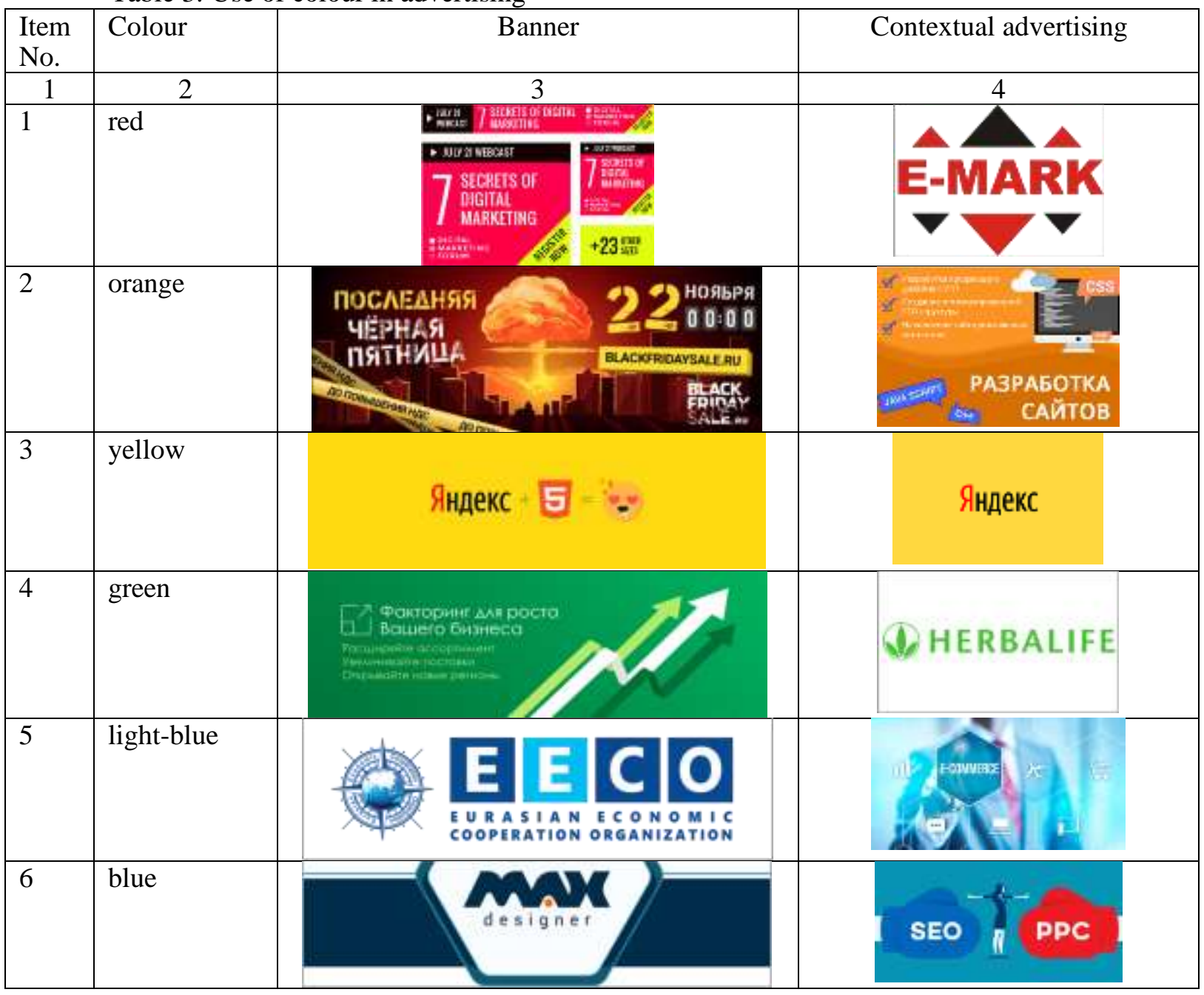


Continuation of table 3 .

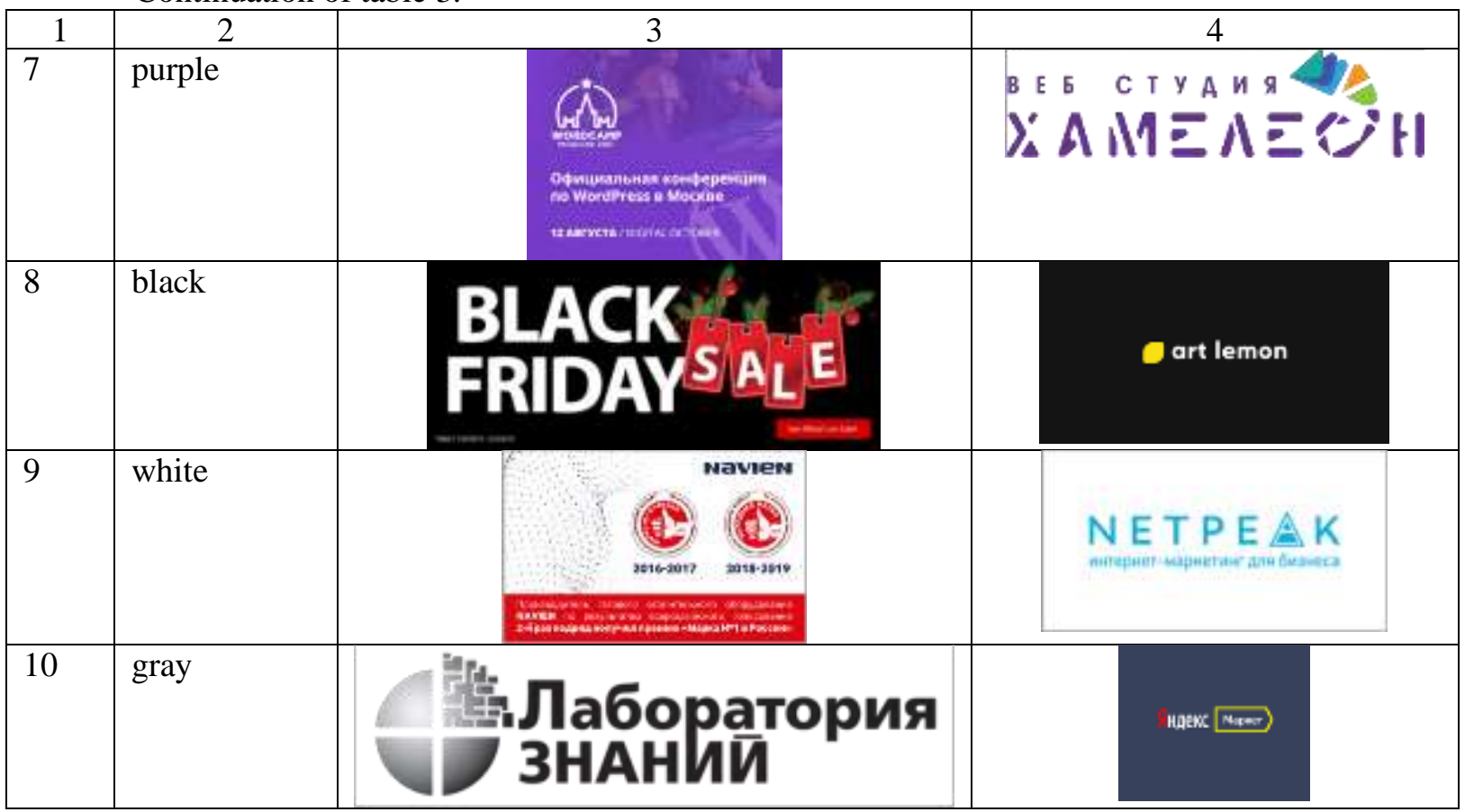

When using yellow, its features should be taken into account. At the physiology level, yellow can cause headaches in some people, so this colour is not used to advertise painkillers. The yellow colour in Russian culture is also the colour of separation, so its use can have the opposite effect when advertising everything related to family values, relationships.

Green is a classic natural colour, so it is well perceived in the advertising of everything related to naturalness, environmental friendliness, even safety (Table 3, item 4). Green causes the following associations: calmness, truthful information, right choice, safe investments, medicines and medicine in general. It should be noted that different shades of green can appeal to different target audiences: light, juicy shades are suitable for children; saturated deep green speaks of stability, inspires confidence, so is suitable for banking and insurance.

Green is one of the safest colours. Its disadvantage is that it does not visually hitches up, as opposed to red.

Light-blue has been widely used on the Internet. This colour is very easy for perception, it does not overload the image, so it is often used in application icons. Light-blue causes positive emotions: calmness, harmony, reliability, confidence (Table 3, item 5). It is associated with freshness, coolness, so it is often used in the advertising of perfumery, cosmetics, water and everything related to it. One of the properties of light-blue is the ability to visually extend space, so it allows introducing lightness into the design.

Light-blue was one of the stereotype themes for boys (light-blue ribbons in maternity homes), so it can be used in limited proportions in the children's products segment.

Close to light-blue is blue. It is more "serious", thorough than light-blue. It is associated with reliability, courage, strength (Table 3, item 6). The main characteristics of this colour work well in children's subjects, because people tend to choose the best quality for children. Here it works in contrast to the frivolous orange (the cheapness association occurs here, which speaks of low quality). Blue does not refer to "flashy" colours, so it does not scare away potential customers. Blue communicates with intelligence, professionalism, authority.

There are the following risks of using blue for banners: dark shades of blue can be depressing and cause associations with official services. Blue is actively used in the business sector, so it is difficult to stand out with it.

Purple has always been perceived as a mystical colour. It causes the following associations that can be used in creating a banner: it is correlated with the luxury segment, sensuality and passion, hedonism (Table 3, item 7). 
This colour is perceived very ambiguously because of its mystical basis and specific influence on the human psyche. He both attracts and repels. It is also important to monitor the nuances of the shades, which is quite difficult in electronic advertising due to the technical features of color reproduction.

Black refers to the classic strict colors, but may have negative associations (Table 3, item 8). The use of a black banner on websites with a light background makes it noticeable, but the black banner can be perceived simply as a dark rectangle, which evokes no interest. Black combined with white and gold alludes to the luxury theme. White works well as a banner background for brightly designed websites (Table 3, item 9). Its plus is the neutrality, the lack of dependence on the reproduction characteristics, it does not overload the page, it is therefore easily perceived, and also attracts attention.

Gray is an intermediate colour between black and white. It is often perceived as formal (Table 3 , item 10). Silver shade is associated with high technology, but metallic shades are not reproduced in the electronic version. In addition, gray can be seen in strong contrast to the colour system of the website. Figure 2 shows a colour scheme for creating a colour palette.

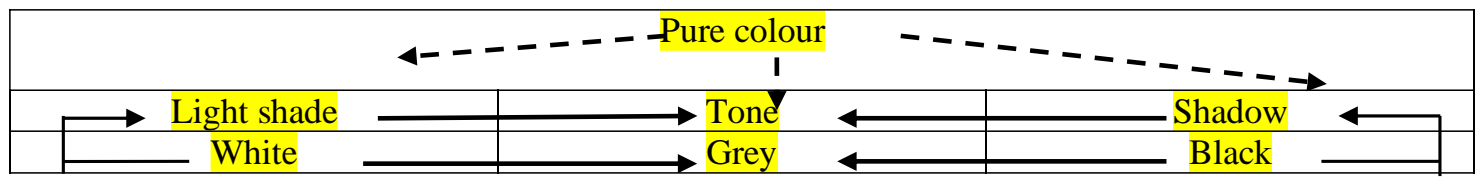

Fig. 2. Scheme of obtaining colour shades to create a colour palette.

Due to the widespread use of the Internet, the constant increase in the number of users, the increased activity of users in the practical use of its opportunities (in addition to entertainment - the purchase and sale of goods and services) [11, p. 141], the problem of availability of electronic information is becoming more urgent.

The availability of visual information is related to the problems of colour blindness. It can be both congenital and acquired. With certain colour schemes, the content of the website for such people may not be available. According to statistics, $6-8 \%$ of men and $0.25-0.5 \%$ of women suffer from different colour vision disorders [12]. If this category of users is of interest to the owner of the resource, it is necessary to consider their peculiarities of colour perception when choosing a colour system.

The manifestations of colour blindness are very individual. For people with severe colour defects, there is special software that optimizes the colour palette of pages to read them. Therefore, it is important for developers to consider only light forms of colour blindness, which users themselves are not always aware of, and which are much more common.

People with a light form of colour blindness experience the following problems when perceiving the colour system:

- distinguishing between red and green colours, with red being more often perceived as green;

- distinguishing between blue and green colours (occurs less frequently);

- distinguishing between blue and yellow colours.

Much less common is a disorder in which all colours are perceived as different shades of gray or a general decrease in visual acuity provokes the blurring of boundaries between zones of different colours. Thus, the biggest problem is the perception of red and its shades. In addition, problems with the perception of form should be taken into account. The simpler the form, the closer its perception is to that of the ordinary person. Sexual identity of the main target audience of the website also plays a role. Men have the greatest difficulty in distinguishing between red and green.

Based on these data, recommendations can be made to take into account the specific colour perception of this group of people. This includes the following items: exclusion of problem pairs (redgreen, blue-green, blue-yellow) from the colour system of the website, they should not be used to indicate the opposite actions; use of a safe colour palette - 216 shades with RGB encoding; use of a homogeneous background and text contrasting with each other; develop the overall design of the page based on shades of gray and blue; use of contrasting colour images where the borders of colours are as clear and sharp as possible.

However, it is important to keep a balance here. It is impossible to fully take into account the peculiarities of the colour system perception by people with disorders, because the design of the website can be critically perceived by people with normal colour perception. Therefore, the ergonomics of all elements, including advertising must be respected for normal users, while it is necessary to ensure the availability of the basic functionality for people with colour perception 
disorders. An example of successful solution to this problem can be the colour palette of Twitter (the colour palette is almost entirely composed of shades of blue) (Table 4).

Table 4. The colour palette of Twitter in the perception of people with different vision quality

\begin{tabular}{|c|c|c|}
\hline $\begin{array}{l}\text { Item } \\
\text { No. }\end{array}$ & Vision quality & Colour palette of the page \\
\hline 1 & no vision deffects & 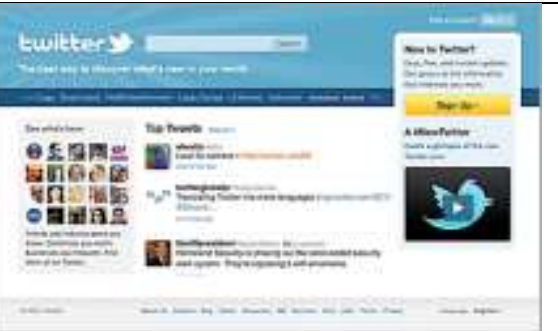 \\
\hline 2 & deuteranopy & 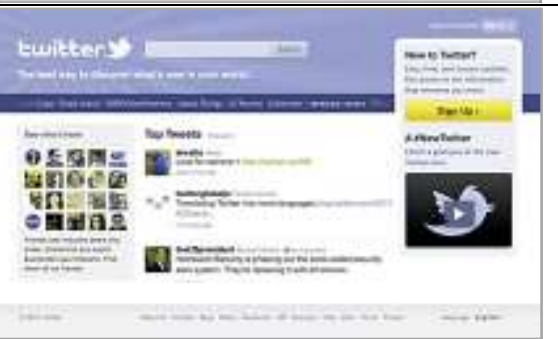 \\
\hline 3 & protanopy & 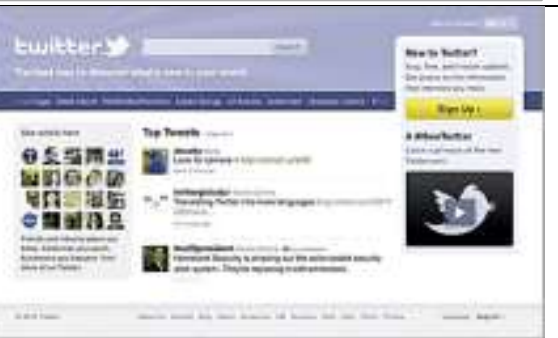 \\
\hline 4 & tritanopy & 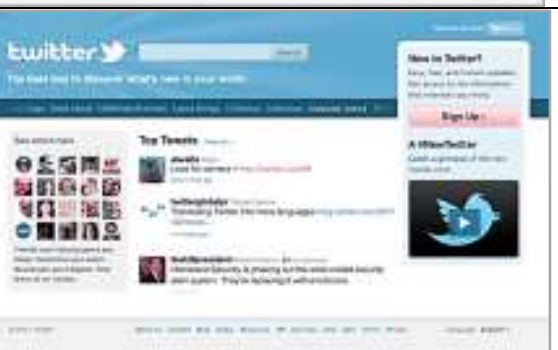 \\
\hline
\end{tabular}

The problem can also be solved more radically - by developing a special design, which will be launched by a button on each page of the resource. It will then be necessary to make this button visually available to optimize the colour scheme.

Conclusions. Technical features of electronic advertising influence the colour system of advertising messages. On the Internet, advertisements on web pages are presented in three main forms: ATL advertising (banner), contextual advertising, search contextual advertising.

In this paper, the focus is on the colour design of the ad units. The main issues in the development of the colour system of electronic advertising were identified in the course of the analysis of the websites presented on the Internet, as well as theoretical and practical achievements on this topic.

In any ad unit, it is necessary to take into account the psychophysiological features of the effects of colour, the traditions of the use of colours, the collective associations of certain user groups, etc. - all those aspects that always come up when working with colour. Next, the nature of the design of the website where the advertising message will be placed shall be considered, and correlated with the colour system of the advertising message. Different forms of advertising work in different colour contexts.

The latest trends in visual advertising development should be taken into account. Advertising often causes the consumer to ignore and/or reject, which is caused by information overload. Therefore, there is such a phenomenon as banner and content blindness, manifested in the subconscious ignoring of advertising on websites with the purpose of screening excess information. It is also suggested to use colour to overcome this phenomenon. 
Another problem was the problem of colour perception disorders in a separate group of users. For this case, the recommendations on the adaptation of the colour system to the features of colour perception by people with disabilities are proposed. They take into account the needs of users with normal colour perception.

However, the fact that colour is currently well studied and analyzed from the standpoint of psychology and physiology should be considered, but the psychological impact of colours in marketing and consumer decision-making, especially in electronic format, is still subjective. Therefore, any solution ideally requires testing [9, p.49].

\section{REFERENCES}

1. Banner Blindness and How to Deal with It: the Psychology of Colour Perception // Medium. - [Electronic resource]. - Available at: https://medium.com/

2. Holyk, D.I., Hanzha, E.A. (2017), The Role of Colour Psychology in Advertising // Modern Technologies: Topical Issues, Achievements and Innovations: Proceedings of the XII International Research and Practice Conference. In 2 parts. Ed. by G.Yu. Huliaeva, Pp. 95-97.

3. Kadantseva, E.E. (2018), Modern Tendencies in Advertising, Marketing and PR // Synergy of Sciences, No. 22, Pp. 265-274.

4. Karpeev, V. Oxford Psychologists on the Psychology of Internet Users: "The Effect of the Combination of Colour of the Website and the Colour of the Ad Units on the Total Consumption (Clicks) of Advertising". Part 1, 2 (translation) // Vovkin blog. - [Electronic resource]. - Available at: http://vovka.su/

5. Kenzina, T.S., Berezhnoy, R.I. (2016), The Concept and Features of Internet Advertising // Young Scholar, No. 27-2 (131), Pp. 15-17. - URL https://moluch.ru/archive/131/36446/ (retrieved 04/09/2019).

6. Manakova, E.V., Yakushina, M.A. (2015), The Influence of Cross-Cultural Differences in Consumer Behaviour on the Perception of Advertising Messages // Bulletin of the Moscow Pedagogical University. Series: Economics, No. 3 (5), Pp. 63-76.

7. Ozirny, V. How to Find a Perfect Colour for a Website // Say-Hi. - [Electronic resource]. - Available at: https://say-hi.me/design/kak-najti-idealnyj-cvet-dlya-veb-sajta.html\#prettyPhoto

8. Romanovich, V.K., Leputina, A.A. (2016), Internet Advertising as a Complex of Tools for Effective Marketing Promotion of Small Business // Economics and Business: Theory and Practice, Pp. 98-101.

9. Saenko, I.I., Kulakova, N.V., Baikova, K.V. (2018), Main Motives and Parameters of Advertising Communication // Modern Economics: Topical Issues, Achievements and Innovations: Collection of Articles of the XVI International Research and Practice Conference: in 2 volumes. Nauka i Prosveshenie Publishing House (Hulyaev G. Yu. PE) (Penza), Pp. 46-49.

10. Sindoyan, G. (2017), Internet Advertising Strategy: Trends, Tools, Directions // SOCIO-ECONOMIC SYSTEMS MANAGEMENT: THEORY, METHODOLOGY, PRACTICE: Collection of Articles of International Research and Practice Conference: in 2 volumes, Nauka i Prosveshenie Publishing House (Hulyaev G.Yu. PE) (Penza), Pp. 112-114.

11. Kharlamova, I.Yu., Shavrova, K.A. (2019), Features of Development of Internet Advertising // WORLD SCIENCE: PROBLEMS AND INNOVATIONS: Collection of Articles of the XXXI International Research and Practice Conference: in 4 volumes, Penza, Nauka i Prosveshenie Publishing House, Pp. 140-142.

12. Tseykovets, N. Ensuring Web Availability for Colour Blinds // Tiflocomp. - [Electronic resource]. Available at: http://www.tiflocomp.ru/docs/webaccessibility2.php

13. Shepeleva, I.N. (2017), The Evolution of Internet Advertising // Humanitarian Accent, No. 3, Pp. 66-70. 